\title{
How Experts Can, and Can’t, Change Policy: Economics, Antitrust, and the Linked Evolution of the Academic and Policy Fields ${ }^{1}$
}

Elizabeth Popp Berman

University at Albany, SUNY

\section{[DRAFT VERSION JANUARY 2017 - COMMENTS WELCOME.]}

\begin{abstract}
During the 1970s, U.S. antitrust policy shifted dramatically from a high-enforcement position to a laissez-faire one, where it has largely remained. At the same time, economics displaced law as the dominant form of antitrust expertise. While these developments are related, the former cannot be reduced to the latter: the median position in economics itself shifted from high-enforcement to low-enforcement during this period, and by its end was moving back toward more enforcement. To understand the relationship between these changes, this paper conceptualizes academic economics and antitrust policy as linked fields with relative autonomy. Though economics came to play a key role in antitrust policy, its influence was in some ways limited. The academic field was itself shaped, though not determined, by outside political interests. In addition, not all academically influential ideas translated equally well into policy. A wide range of economists shared a commitment to efficiency as the main purpose of antitrust, however, which delegitimized other historical goals of antitrust policy and constrained political possibilities in lasting ways.
\end{abstract}

\footnotetext{
${ }^{1}$ I would like to thank Jing Li and Josh McCabe for excellent research assistance, and Nitsan Chorev, Dan Hirschman, Ellie Shermer, Yingyao Wang, and Viviana Zelizer for helpful comments on an earlier, and much different, version of this paper. I have benefited from audience feedback at annual meetings of the Social Science History Association and the American Sociological Association, as well as at the Institute for Advanced Study, Princeton University, and Boston University.
} 
Antitrust policy, which establishes the rules that govern markets, should be of central interest to economic sociologists. Yet with notable exceptions (Davies 2010; Davies 2014; Dobbin 1994;

Dobbin and Dowd 2000; Fligstein 1990; Prasad 2012), it has received little attention, despite the fact that in the 1970s, it underwent a transformation that changed the way firms are embedded in social institutions. In the 1960s, the modal position in the field of antitrust policy was characterized by a deep suspicion of bigness, a reluctance to allow many types of mergers, and an assumption that restraints on trade were likely anticompetitive. By the early 1980s, that position had shifted to hold that vertical and conglomerate mergers were almost never problematic, that horizontal mergers only became problems at very high levels of concentration, and that many restraints actually promoted consumer welfare. ${ }^{2}$

This transformation went hand in hand with a change in the dominant form of expertise in antitrust policy. At the outset of this period, the field was led by attorneys who saw antitrust as balancing multiple goals, and understood the job of government as aggressively enforcing antitrust laws as interpreted by the courts. By its close, the field was led by economists, who saw consumer welfare, generally defined as allocative efficiency, as the sole goal of antitrust policy, and the job of government as identifying firm behaviors that were welfare-reducing, and preventing them.

Yet while the two changes are related, one cannot be reduced to the other. First, economists' position evolved during this period. Since the 1960s, several schools of thought (the structure-conduct-performance [SCP] framework, the Chicago School, and post-Chicago game theoretic approaches), each with different implications about what antitrust policy should look

\footnotetext{
${ }^{2}$ Horizontal mergers are between competitors in the same market; vertical mergers are between companies at different points on the supply chain; conglomerate mergers are between companies operating in different markets entirely.
} 
like, have successively taken the lead. The economists who initially made inroads into antitrust policy used an SCP approach and supported what now look like very high levels of intervention. They were soon, with support from interested groups from outside academia, replaced by laissezfaire proponents of the Chicago School. The Chicago School was in turn displaced by postChicago game theorists, who envisioned more circumstances under which government might sensibly intervene in markets.

The extent to which antitrust policy has been captured by experts, and its problems defined as technical and economic, rather than social and political, makes it useful for thinking about the relationship between politics and expertise more generally. Rather than asking whether experts have independent effects on politics or simply reflect the interests of powerful actors, a debate that goes back at least to Marx, I ask how, in a policy field dominated by experts, politics is structured by expertise.

To do so, I treat antitrust policy and academic economics as linked fields (Abbott 2005; Fligstein and McAdam 2012) with relative autonomy from one another. ${ }^{3}$ In the 1960s and 70s, academic economists entered the policy field and successfully institutionalized a role for themselves - in Abbott's terms, creating an "avatar" for economics. In the process, and given favorable political circumstances, antitrust policy was legally redefined by the courts from having competing, often conflicting goals_-promoting competition, protecting small business, limiting economic power-to focusing solely on consumer welfare, a goal that could be pursued using the tools of economics.

But the capture of antitrust by experts did not remove politics from antitrust policy. Instead, politics was channeled through expertise. Increasingly organized business interests

\footnotetext{
${ }^{3}$ Abbott discusses linked ecologies, not fields, but I borrow the term in the hope that it does not do too much violence to the original. On the difference between field and ecology, see Liu and Emirbayer (2016).
} 
supported the Chicago School financially, and an increasingly conservative Supreme Court favored its prescriptions.

Yet interests alone cannot explain the continued evolution of economics. Though Chicago did have the support of generous donors, its defeat of SCP can also be attributed to stakes specific to the academic field-its intellectual appeal. And just as the interventionism of SCP produced a Chicago reaction, the fractal dynamics of the discipline (Abbott 2001) produced game theoretic industrial organization, which resurrected some of SCP's concerns. By the late 1980s, game theory was sweeping the academic field, even though it lacked the outside support that had benefited Chicago.

The links that had been established between the academic and the policy fields ensured that new ideas flowed quickly from one to the other. But not all schools of thought had the same political affordances (Gibson 1977; Norman 1990). While Chicago provided guidance that was clear and useful for judges, game theory, while able to explain how firm behaviors might be competitive under some circumstances and anticompetitive under others, was much less helpful in providing guidelines that could be applied to specific cases of the sort courts would encounter. Thus even as post-Chicago approaches became dominant in the academic field, and were clearly being transmitted to the policy field, they failed to fully take hold either in the enforcement agencies or, especially in the courts, even though economics remained the main framework for thinking about antitrust policy.

But while politics, now refracted through the discipline of economics, continued to play out in antitrust policy, that did not mean that the capture of antitrust by experts itself had no political effects. While some schools of thought suggested more intervention and others suggested less, a commitment to efficiency as the sole goal of antitrust policy was consistent 
across economic approaches. Broader, historically relevant goals for antitrust policy—notably, a concern with the economic power of corporations, as opposed to their market power-remained illegitimate, as pursuing them seemed to require tools that went beyond the scope of economics, and might conflict with it. ${ }^{4}$ Thus while a variety of political positions may continue to play out in a policy domain captured by experts, to the extent that the capturing discipline has, like economics, a stable "core" (Reay 2012), debate will remain within the range of possibilities that are compatible with that core.

\section{Experts, Ideas, and Politics: A Framework for Understanding Antitrust Policy}

Debates over the role of experts in politics are of long standing in sociology. For Marx and his followers, ideas and the intellectuals who develop them primarily reflect the interests of the capitalist class. In the 1980s, however, state-centered theorists (e.g. Weir and Skocpol 1983) began to attend to the way that state structures themselves might favor some experts and their ideas, and others might not.

For both state-centered theory and Marxian political sociology, however, the success of ideas was essentially a dependent variable - to be explained by either state structures (for the former), or class interests (for the latter). As state-centered theory evolved into historical institutionalism, however, attention to the independent role of ideas in politics increased (Derthick and Quirk 1985; Hall 1989; Hall 1993; Weir 1993). By the turn of the century, sociologists (Campbell 1998; Campbell 2002) and political scientists (Berman 1998; Blyth 2002; McNamara 1998) were making stronger claims about the causal force of expert ideas, and by 2005, Somers and Block could argue in the American Sociological Review that some ideas were

\footnotetext{
${ }^{4}$ Market power is the ability to raise prices above their competitive level; economic power, here, refers to broader political and economic impacts that a firm might have.
} 
so inherently powerful that they could fuel "radical transformations" (260) in politics.

Of course, such strong claims have not gone without critique (e.g. Prasad 2006). Yet throughout this literature the organizing question has remained whether ideas have independent causal effects (and if so, when), or whether their impact simply reflects preexisting political interests or the structure of state institutions.

There have, particularly in the last five years, been exceptions to this dichotomization. Medvetz (2012) characterizes think tanks as existing at the intersection of the academic, political, economic, and journalistic fields. Campbell and Pedersen (2014) show how regimes of policy knowledge vary across nations. Other scholars have shifted from a focus on ideas and the experts who carry them to a "sociology of interventions" (Eyal 2013; Eyal and Buchholz 2010), or otherwise looked to complicate the story of how experts and politics intersect (Fairbrother 2014; Mudge and Vauchez 2012). I build on such work in explaining how politics and expertise have intersected in the case of antitrust policy.

I treat antitrust policy and academic economics as distinct, but linked, strategic action fields (Abbott 2005; Fligstein and McAdam 2012), and assume that experts originating in the academic field work to institutionalize a role for themselves in the policy field - establish an avatar (Abbott 2005) — through organizational, legal, or cultural means. Other groups who see the success of such experts as aligning with their interests will support their efforts.

I also assume that the academic field has relative autonomy (Bourdieu 1993) from the policy field, and that action in each field is pursuing field-specific stakes - political actors pursuing political influence; academic actors pursuing academic status - even though some individuals may be acting in both fields simultaneously. Thus each field, and the actors within it, will evolve according to its own logic, even as the links between them mean that they continue to 
affect one another.

To understand the coevolution of these fields, I draw on three additional concepts. First, academic economics exhibits fractal cycles of the sort Abbott (2001:22) describes. One school of thought produces another that is built on concerns unattended to by the first; the second defeats the first, but quickly generates a new line of work that takes up concerns of the now-defeated first that the second school deemphasizes, and so on.

Second, I borrow the concept of affordances (Gibson 1977; Norman 1990), which has been used widely to describe how particular technologies provide the potential for some kinds of action but not others (Gaver 1991). I suggest that knowledge, like technologies, may afford some possibilities but not others. In particular, some theories produce knowledge that, simply because of the kind of knowledge it is, is useful and usable for particular actors in the policy field, while others, regardless of their truth or the accuracy with which they describe the world, do not.

Finally, I use Reay's (2012) insight about the stable “core” of economics to distinguish between particular theories or intellectual positions that may evolve over time with the development of the field or be advocated by economists with different political preferences, and those (like a commitment to efficiency) that, so long as the discipline remains influential, are likely to remain central despite the evolution of schools of thought within it.

The paper develops these arguments using an abductive strategy (Tavory and Timmermans 2014) focused on a single case. However, it is based on a larger project examining the role of economics in several U.S. policy domains, involving exploratory research on science and tax policy, and more detailed study of welfare, environmental, and regulatory policy. The research draws on primary and secondary sources, several dozen oral histories, and documents from seven archives. Its starting point was broadly institutional, and began with the assumption 
that the policy domains could be treated as fields (Fligstein and McAdam 2012) in which one could identify competing logics (Thornton, Ocasio and Lounsbury 2012), and that some of these logics would be associated with the discipline of economics.

While the cases were chosen because economic logics were visible within them, there was considerable variation in what role economics played across policy domains. In science policy, for example, economic logics were widespread and clearly originated with academic economics, yet economists themselves had little direct influence on the policy process (Berman 2012). In other areas, though, like regulatory policy, academic economists played a more direct role, becoming a sort of obligatory passage point (Callon 1986) through which other political actors had to pass (Berman forthcoming).

Antitrust policy was a strong example of the latter type of case. Economists had not only become influential themselves, but their way of thinking about antitrust policy had reshaped legal thought and been institutionalized as the only legitimate form of reasoning through court decisions. Thus I chose to focus on antitrust policy as a starting point for understanding a particular type of strong expert influence. ${ }^{5}$

The standard strategic-action-field story in which a group of actors advocates a new way of thinking about a field, gradually institutionalizes that conception of the field, and then sees that conception shape subsequent action with the field, fit the case in broad strokes. Economists were able to institutionalize a definition of the antitrust field in which efficiency was the primary policy goal, and competing goals of antitrust were delegitimized.

However, this seemed to overlook an important part of the story: that while an economic conception of the field was established and has remained dominant for several decades, the

\footnotetext{
${ }^{5}$ Monetary policy, which I have not examined in any depth, would be another obvious case of strong influence.
} 
theories economists used to understand the field and the political positions they have taken evolved considerably during that time. This led to a return to theory, and in particular to a borrowing of the concepts of linked fields with relative autonomy, fractal cycles, and political affordances to better explain the case. Integrating these additional ideas with the standard institutional story about the establishment of new logics provided a much fuller, yet still coherent, account of the transformation that took place in antitrust policy, while also providing a starting point for thinking more generally about the relationship between politics and expertise.

\section{The Field of Antitrust Policy to the 1960s}

Antitrust policy in the United States dates back to the Sherman Anti-Trust Act of 1890, passed to rein in the trusts that had come to control major industries like oil and steel. The Sherman Act banned agreements to restrict trade, monopoly, and the intent to monopolize, but was weakly enforced. In subsequent decades it was strengthened and expanded with the Clayton Act and the Federal Trade Commission Act (both passed in 1914), and the Robinson-Patman Act (1936). Collectively, these laws prohibited anticompetitive mergers, price discrimination, and a number of other types of restraint on trade. Two federal agencies - the Antitrust Division of the Department of Justice (DOJ) and the Federal Trade Commission (FTC) - were given the authority to enforce them. ${ }^{6}$

The major antitrust statutes are relatively brief - the Sherman Act is less than a thousand words in length — and leave much to the imagination. Thus the most important actors in the field of antitrust policy have historically been the Antitrust Division and the FTC, which enforce the

\footnotetext{
${ }^{6}$ The U.S. Attorney General, who leads the Department of Justice, and then then the Assistant to the Attorney General, were initially responsible for antirust enforcement until the Antitrust Division of the DOJ was created in the 1930s. The FTC was given its powers when it was created by the Federal Trade Commission Act of 1914.
} 
law, and the courts, which interpret it. Antitrust policy has also been intermittently shaped by Congressional interest, which has come in waves, and presidential priorities, which are expressed primarily through high-level political appointments to the relevant executive agencies. In addition to government actors, a range of industry and consumer interests have also played a role in the policy field.

Two historical features of antitrust policy are important for the present story. First, antitrust enforcement has come in waves, as policymakers and the public react to industry developments (like the early-twentieth-century merger wave that preceded the Clayton and FTC Acts) or economic and social change (like the Depression-era threat to small businesses by chain stores that led to the Robinson-Patman Act). Each of these waves has been separated by a period of relative disinterest or lesser enforcement.

The longest and strongest wave of antitrust enforcement began in 1945, when a federal court reversed the presumption that "the law does not make mere size an offense" and instead found that dominant market position and a history of purposive expansion were enough grounds to challenge mergers. This was followed by the 1950 passage of the Celler-Kefauver Act, which, by closing a loophole in the Clayton Act, effectively "convinced firms that horizontal and vertical mergers were illegal" (Fligstein 1990:196). This wave continued and even intensified into the 1960s.

Second, from its earliest days antitrust policy reflected multiple, and often conflicting, purposes. Antitrust scholars disagree on the primary intent of the Sherman Act and its successors. They have made cases that it was to protect competition (Orbach 2013); increase consumer welfare, often defined specifically as allocative efficiency (Bork 1978; Dameron 2016); limit economic power (Millon 1988); protect small business (Levinson 2011); and 
redistribute wealth (Lande 1982). And each of these goals is visible at particular moments in antitrust history. For example, the Robinson-Patman Act was aimed at small business (Patman and Robinson 1938), while other antitrust legislation prioritized efficiency. What nearly all scholars agree on, though, is that the original intent of antitrust legislation was complex and open to interpretation. ${ }^{7}$ Moreover, different antitrust goals were often at cross-purposes with each other: protecting less-efficient small businesses might mean higher prices for consumers.

Until the 1970s, law was clearly the dominant form of expertise in the field of antitrust policy (Hovenkamp 2015), but economics has always been present as well. In the early twentieth century, and particularly during the Depression, economists were fairly visible in antitrust debates. But the policy-relevant economists of the day were institutionalists, not neoclassicals (Barber 1996; Mayhew 1998).

After the 1930s there was a divergence between academic economics and antitrust policy. Legal realists - the "lawyer branch of institutionalism" - continued to dominate law, while in economics institutionalism was being replaced by marginalism. As a result, legal policymakers largely abandoned economics as a discipline, producing a "sharp divide between economic theory and government policymaking" (Hovenkamp 2015:110; see also Medema 1998). By the 1950s, while academic economists were conducting a considerable amount of research on antitrust issues, they played a limited role in antitrust policy.

While both the Antitrust Division and the FTC had offices for "economics," they employed relatively low-skilled workers and were marginal to the larger organizations. The Antitrust Division, for example, had an "Economic Section," which in 1962 employed twentysix "professional economists" (Markus 1962:14). But few of these had an advanced degree, and

\footnotetext{
${ }^{7}$ Not all, of course; see Bork (1978).
} 
even the section's chief, Lewis Markus, lacked a PhD. Markus called his employees “assistants to the legal staff" and emphasized their subordination to lawyers; a subsequent antitrust chief referred to these economists, dismissively, as "people who made charts for litigation" (Kauper 2007; Markus 1962:17).

Similarly, the FTC had a Bureau of Economics, which a later director described as being, circa 1960, "the graveyard of the FTC" (Pautler 2015:125, 127). Its director, too, emphasized economists" "support" role at the agency (Mueller 1962:21). Though the situation began to change during the 1960s, as late as 1971 one observer could write that "[i]n antitrust cases, it has been widely held that there is little need for economic expertise" (Wagner 1971:84).

\section{The Field of Academic Economics to the 1960s}

That is not to suggest, however, that mid-century neoclassical economists had nothing to say about antitrust. In fact, a whole subfield of economics, industrial organization, developed during this period to answer questions about when markets performed efficiently. Industrial organization (I/O) originated with 1933 books by Edward Chamberlin and Joan Robinson, both of which used a marginalist, microeconomic framework for thinking about the conditions under which monopolistic behavior was likely to emerge. In the next two decades, Edward Mason (like Chamberlin, at Harvard) and his student Joe Bain developed the structure-conduct-performance (SCP) paradigm that dominated the field for several decades (Shepherd 2007). ${ }^{8}$

The SCP framework (also known as structuralism, or the Harvard School) argued that industry structure determined firm conduct, which in turn predicted industry performance. In a highly concentrated industry, large firms would take advantage of their market power by keeping

\footnotetext{
${ }^{8}$ For a more nuanced reading of positions within the broad church of structuralism, see Peritz (1996).
} 
prices high; an industry in which firms could keep prices above marginal cost would have deadweight losses and produce allocative inefficiency. ${ }^{9}$ While neoclassical in its foundations, structuralism also inherited some of institutionalism's legacy with its detailed, descriptively rich studies of specific industries (Hovenkamp 2009).

SCP assumed economies of scale were not substantial in most industries, that barriers to entry were large and could be manipulated by dominant firms, and that pricing above marginal cost began at relatively low levels of concentration (Hovenkamp 1985). While it left room for disagreement about when exactly government should intervene, it clearly implied that government should act to limit industry concentration and a wide range of firm behaviors it saw as anticompetitive.

The Harvard School dominated I/O during the 1950s and 60s; Bain's 1959 textbook, Industrial Organization, led the field into the 1970s (AER 1983). But at the same time, a competing approach was developing at the University of Chicago, where Aaron Director led first the Free Market Study (1946-52), and then the Antitrust Project (1953-57). At the outset of this period, Director believed that government needed to limit corporate concentration, but in the decade that followed his position gradually reversed (Van Horn 2009). He and his students began to develop a different position, empirically challenging common assumptions of the field, such as that Standard Oil had been engaging in predatory pricing in the late nineteenth century (McGee 1958). ${ }^{10}$

Joined by George Stigler in 1958 and training students (notably Robert Bork) who would shape the field's future, Chicago's price theoretic approach to I/O did not assume one could infer much about firm conduct or industry performance from industry structure. Instead, it suggested

\footnotetext{
${ }^{9}$ That is, it would reduce the sum of consumer and producer gains from trade.

${ }^{10}$ See, e.g., Henry Simons' A Positive Program for Laissez Faire, reprinted in Simons (1948).
} 
that size was generally an indication of efficiency and not monopoly power, that predatory pricing was usually not possible even for very large firms, and that many practices then seen as anticompetitive, like resale price maintenance, actually increased efficiency (Director and Levi 1956; Posner 1979). The Chicago approach implied a much smaller scope for antitrust policy, limited to the prevention of price-fixing and perhaps very large horizontal mergers. ${ }^{11}$

Neither Harvard nor Chicago I/O economists were well-represented in Washington during this time. But both schools had close ties to academic law, and these would grow closer in the 1960s. At Harvard, Ed Mason ran an antitrust law and economics seminar with two of his former PhD students (Carl Kaysen, also on the economics faculty, and Donald Turner, appointed in the law school), and law professor Kingman Brewster (Fisher 2012:340-341). Kaysen and Turner's 1959 treatise, Antitrust Policy: An Economic and Legal Analysis, applied the SCP framework in ways useful to attorneys, not just economists, and became a landmark in the field. At Chicago, Aaron Director's appointment was in the law school; he founded the Journal of Law and Economics in 1958 and trained lawyers (Bork, Henry Manne) as well as economists.

Harvard was clearly the stronger of the two schools throughout the 1960s. In the late 1960s, ten of the fifteen most-cited scholars in antitrust law were economists or economicsfocused lawyers; seven of these were structuralists (Turner and Bain held spots one and two on the list), and only two were Chicago School (Stigler, at number five, and Bork at eleven; Eisner 1991:110). ${ }^{12}$ Yet Chicago was clearly on the rise. Stigler was doing some of his most significant work on industrial organization (e.g. Stigler 1961; Stigler 1964; Stigler and Friedland 1962). Antitrust Project alumni Bork and Ward Bowman were advancing the Chicago position as Yale

\footnotetext{
${ }^{11}$ [Add Chicago archival evidence here.]

${ }^{12}$ Eisner reviewed articles published in the two main antitrust law journals between 1965 and 1970. The tenth economist was institutionalist John Kenneth Galbraith.
} 
Law faculty. Ronald Coase had arrived at Chicago, and by the end of the decade Richard Posner would join him.

The competition between the two schools, however, was at this point driven largely by stakes specific to the academic field. The schools clearly had different political affinities, and Chicago economics was well-connected with influential conservatives (e.g. Burgin 2012). And in subsequent decades significant money would flow to support the Chicago position (e.g. Miller 2006). Yet before the second half of the 1960s, none of the main players was yet actively involved in the field of antitrust policy. And while some authors have emphasized the Antitrust Workshop's early support by the conservative Volcker Fund (Van Horn 2009; Van Horn and Mirowski 2009), this funding was modest—hardly enough to launch a movement on. If anything, Harvard, with its close ties to the Northeast establishment, seems more likely to have had plentiful access to resources during this period.

\section{Advancing Economics in the Field of Antitrust Policy}

The 1960s saw antitrust enforcement reach a high-water mark. Congress and the KennedyJohnson administrations generally supported strong enforcement of the antitrust laws (Williamson 1995). But it was the combination of an aggressive Antitrust Division and a sympathetic Supreme Court that most directly produced an exceptionally expansive set of judicial decisions. $^{13}$

The Antitrust Division was dominated by attorneys, who took what might be called an enforcement approach to antitrust. Rooted in both professional norms and career interests, attorneys saw their role not as evaluating whether particular firm behaviors were good or bad,

\footnotetext{
${ }^{13}$ The FTC was relatively moribund during this period; see ABA (1969); Cox et al. (1969).
} 
but as challenging as many as could be legally justified (Eisner 1991:16-17). This tendency was reinforced by the late-1950s introduction of an honors program that recruited attorneys from the top $10 \%$ of their classes at a select set of law schools. This led to an influx of ambitious young men $[s i c]$ with strong career incentives to gain litigation experience, which strengthened the AD's existing inclination toward strong enforcement (Eisner 1991:86-87).

For most of the decade, the Supreme Court seemed happy to go along with these aggressive challenges. In Brown Shoe (1962), for example, the Court invalidated a merger that would have given the firm in question a 5\% share of the market, while Von's Grocery (1966) stopped a supermarket merger that would controlled $7 \%$ of the market in Los Angeles alone. ${ }^{14}$

In making these and other decisions, the Court drew on several conflicting conceptions of what antitrust policy was for, reflecting the competing visions of antitrust that had long been inherent in the enterprise. Some decisions reflected, at least in part, the economic goal of maximizing consumer welfare. In Philadelphia National Bank (1963), for example, the Court emphasized that "[t]he test of a competitive market is not only whether small competitors flourish but also whether consumers are well served...In an oligopolistic market, small companies may be perfectly content to follow the high prices set by the dominant firms, yet the market may be profoundly anticompetitive." 15 It emphasized that its decision was "fully consonant with economic theory," and cited several economists, including Kaysen and Turner, Stigler, Bain, and Mason, in support of its argument. ${ }^{16}$

Yet other cases reflected competing concerns about either the protection of small business or the dangers of economic concentration. Brown Shoe, for example, explicitly rejected

\footnotetext{
${ }^{14}$ Brown Shoe Co. v. the United States, 370 U.S. 294 (1962); United States v. Von's Grocery Co. et al., 384 U.S. 270 (1966).

${ }^{15}$ United States v. Philadelphia National Bank et al., 374 U.S. 321 (1963), at*367.

${ }^{16}$ Ibid, at *363.
} 
consumer welfare as the sole standard for antitrust: "we cannot fail to recognize Congress' desire to promote competition through the protection of small, locally owned businesses. Congress appreciated that occasional higher costs and prices might result from the maintenance of fragmented industries and markets. It resolved these competing considerations in favor of decentralization." ${ }^{17}$ Similarly, Von's Grocery emphasized that "the basic purpose of the 1950 Celler-Kefauver Act was to prevent economic concentration in the American economy by keeping a large number of small competitors in business." ${ }^{18}$ Even in Philadelphia National Bank, in which the Court said consumer welfare mattered, it did not entirely dismiss the protection of small business.

Recognizing conflicting purposes for antitrust policy made for poor law, however. Even some observers who were skeptical of industry concentration were uncomfortable with the lack of systematic justification underpinning its rejection. As Justice Potter Stewart famously wrote in his dissent to Von's, “The sole consistency I can find is that in litigation under $\S 7$ [of the Clayton Act], the Government always wins." 19

This was the environment into which academic economics first began to make inroads back into antitrust policy. While Harvard and Chicago I/O were opposed in many ways, as representatives of (broadly) neoclassical economics, they shared the belief that the purpose of antitrust policy should be to maximize consumer welfare, understood as allocative efficiency. In general, economists thought that the competing logics considered by antitrust policy were either in outright conflict with economics (protecting inefficient small businesses) or simply muddied the waters (limiting firms' broader economic power, for example, as opposed to their specific

\footnotetext{
${ }^{17}$ Brown Shoe, 370 U.S. 294 (1962), at *344.

${ }^{18}$ Von's Grocery, 384 U.S. 270 (1966), at *275.

${ }^{19}$ Von's Grocery, at *302.
} 
market power to raise prices above their competitive level).

This was the vision that Don Turner, Harvard law professor and Harvard economics $\mathrm{PhD}$, brought to the Antitrust Division when President Johnson appointed him chief in 1965. Turner made it clear that he wanted the AD to move away from the presumption of "bigness is badness," and instead to bring cases that had a clear economic rationale. He stated publicly that he would "not necessarily file every case he kn[ew] he could win," a position with which some in the Division "deeply disagree[d]" (Shanahan 1966:65). And he called cases in which the courts had argued that increased efficiency was anticompetitive, because more efficient larger businesses could outcompete smaller ones, "not only bad economics but bad law" (Turner 1964:1324).

It was an uphill battle, but during the next three years Turner took several steps to move the Antitrust Division in this direction. First, he expanded the policy planning office, which reported directly to him, and asked it to review proposed cases to make sure they were economically as well as legally justifiable. The Division's lawyers hated this process. “[S]omeone had, in the lawyers' eyes, changed the criteria of review, adding standards alien to the lawyers and repugnant to their notions of good prosecution. One did not turn down a case involving a clear, predatory violation of the law simply because it had little economic impact" (Weaver 1977:134). This change had limited long-term impact, as the next antitrust chief, who was less economically inclined, stopped using the policy planning office for this purpose (Weaver 1977:135).

Second, Turner brought in a "special economic assistant": a young academic economist appointed to serve for a year, reporting directly to the chief. The special economic assistants were highly qualified individuals with $\mathrm{PhDs}$ from elite economics departments; Turner's second assistant, for example, was Oliver Williamson (Williamson 2002). Though a modest change, the 
new position would persist after Turner left.

Finally, and most importantly, Turner developed the first set of merger guidelines, which explained when the Division would challenge mergers. Based in structuralist logic, in which level of concentration could predict anticompetitive behavior and thus market efficiency, and grounded in recent court decisions, they laid out specific standards at which mergers would “ordinarily" be challenged. For example, in a highly concentrated market (CR4 > about 75\%), one could expect a challenge if the acquiring firm held $4 \%$ of the market and the acquired firm $4 \%$ or more, or if the acquiring firm held $10 \%$ of the market and the acquired firm $2 \%$ or more, and so on. ${ }^{20}$ The 1968 Merger Guidelines made no reference to economic power or the virtues of small business, but emphasized that "the primary role of Section 7 [of the Clayton Act] enforcement is to preserve and promote market structures conducive to competition" (U.S. DOJ 1968:1-2). While it was initially unclear whether the courts would defer to the new guidelines, it turned out that they were taken seriously (Greene 2006; Newborn and Snider 1992). ${ }^{21}$

Thus the late 1960s saw neoclassical economics make its first real, if modest, inroads into the field of antitrust policy, advocating for a specifically economic definition of the goals of antitrust policy. Like the enforcement-focused lawyers whose turf he was encroaching on, Turner supported high levels of government intervention. As his deputy, Edwin Zimmerman, later wrote, "No massive incongruity between the legislative goals and an economically oriented enforcement policy was seen since the oligopoly theories [i.e. structuralism] relied upon rules that also helped implement noneconomic legislative goals" (Zimmerman 1990:455).

But while Turner's reforms were moderately successful, they met considerable resistance

\footnotetext{
${ }^{20} \mathrm{CR} 4$ is the four-firm concentration ratio; i.e., the percentage of the market controlled by the four largest firms in it.

${ }^{21}$ [Add LBJ archival evidence here]
} 
along the way. His efforts rubbed Division attorneys the wrong way not because of the conclusions he arrived at but the logic he used to reach those conclusions. Had Turner represented the Chicago School, with its laissez-faire recommendations for antitrust policy, it seems unlikely he would have made even the headway that he did. But the inroads he made for SCP economics in the 1960s opened the door for a very different type of economics in the 1970s, as both the academic field and the policy field continued their separate evolution. ${ }^{22}$

\section{The Double Rise of Economics in the Policy Field and Chicago in the Academic Field}

The early 1970s saw efforts to increase the role of economics at the Antitrust Division intensify, and be joined by a similar project at the FTC. After the tenure of a less economically inclined antitrust chief from 1969 to 1971, Thomas Kauper, a Michigan law professor with an undergraduate degree in economics, and not closely associated with either the Harvard or Chicago Schools, was appointed AAG. He had already made the case for making economic goals more central to antitrust policy, writing that "[i]f protection of independent judgment, individual initiative, and equality of opportunity is achieved at the cost of economic efficiency, the price may be too great" (Kauper 1969:334). Kauper was joined by George Hay, a similarly unaligned Yale microeconomist who started as Kauper's Special Economic Assistant.

While the AD had long had an Economic Section, in 1973 its longtime director retired, and Kauper and Hay saw the opportunity to upgrade (Williamson 2002). They created a new Economic Policy office (EPO), led by Hay and staffed by economics PhDs from top departments. Learning from Turner's mistakes, Kauper and Hay strategized about how best to

\footnotetext{
${ }^{22}$ Although Willard F. Mueller, director of the FTC's Bureau of Economics in the 1960s, did expand that department from the low point it found itself at when he arrived, as a Wisconsin institutionalist in an agency that was widely seen as ineffectual, it does not seem that his efforts to advance economics into antitrust policy enjoyed the same success as Turner's - though see Mueller (2009).
} 
integrate economics into agency decisionmaking while minimizing the ire it raised from litigators. They involved economists early in the case selection process, rather than having them review cases at the end. Indeed, they found ways to make the EPO generate economically rational cases that the lawyers might otherwise overlook - thus countering economists' in-house reputation as “case-killers” (Eisner 1991; Hay 2008; Kauper 1984; Kauper 2007).

In addition, they made an effort to teach the lawyers basic economics, first through a retreat where Kauper "brought in a couple of economists just to sort of lecture" the section chiefs and their assistants, and then through "a mandatory course taught by George Hay" (Kauper 2007). During this period, it became much harder for the Antitrust Division to put together a case that was not economically rational, even if it was in theory litigable, because the economists could quickly head it off, and the lawyers better understood why they were doing so.

The FTC also dramatically upgraded its capacity for economic analysis in the 1970s. As part of a major reorganization at the beginning of the decade, the agency expanded and professionalized its Bureau of Economics, and appointed H. Michael Mann and then Frederic M. Scherer, both economics faculty working in the SCP tradition, to lead it. Over the decade, the Bureau's staff doubled from 40 to 80 economists. While at the outset only $20 \%$ held PhDs, by the end of the decade most did, and the rest were ABD. Increasingly, these economists' degrees were from top schools (Eisner 1991). ${ }^{23}$

The new staff were not only better trained, but were more independent as well. In a dramatic reversal from the previous decade, they stated, "We're not staff support for the attorneys and we're not hired to draw up statistical tables" (Katzmann 1980:40). Increasingly, as at the Antitrust Division, their perspective came to dominate. By the mid-1970s, one economist

${ }^{23}$ Only six of the original forty remained as of 1977 (Katzmann 1980:37-38). 
could say, "It wasn't too long ago that the lawyers would only ask: 'what does the law say?'... Now, economic principles are usually controlling, even among the attorneys" (Katzmann 1980:49).

\section{The Changing Policy Environment}

The change in the role of economics was taking place in the context of a rapidly evolving political environment. Nixon entered office putatively committed to strong antitrust enforcement, and his first AAG, Richard McLaren, was a vocal skeptic of conglomerate mergers. But Nixon also promised ITT (International Telephone \& Telegraph), a target of a DOJ merger investigation, that the investigation would be dropped in exchange for a donation to the Republican National Convention. When McLaren proved resistant to this suggestion, Nixon suddenly made him a federal judge and tapped Kauper, about whom little was known except that he did not oppose conglomerate mergers, as a replacement (Feldstein 2010; Kauper 2007). More lastingly, Nixon also had the opportunity to appoint four Supreme Court Justices between 1969 and 1971. With the liberal Warren Court replaced by the conservative Burger Court, the stage was set for a different judicial approach to antitrust.

Outside of government, two political movements were also changing the antitrust landscape. On the one hand, Ralph Nader's consumer movement brought new attention to antitrust issues (e.g. Green 1972). The Nader group's scathing report on the ineffectual FTC (Cox, Fellmeth and Schulz 1969) led to a follow-up investigation by the American Bar Association (ABA 1969) and, in 1970, to major reforms that would increase the agency's statutory authority, staff quality, and budget (Harris and Milkis 1996). The consumer movement would also align with the old guard of Congressional antitrust supporters to push, mostly 
unsuccessfully, for new antitrust legislation that "sought to evade the power of the growing body of efficiency-based economics that threatened to eliminate antitrust policy as economic egalitarianism" (Sims and Herman 1997:873).

At the same time, business elites were also becoming increasingly organized in the early 1970s. The expansion of government regulation, a challenging economic environment, and a general perception that business was under attack led to the formation of new organizations like the Business Roundtable, the rejuvenation of groups like the Chamber of Commerce, and a wave of business support for conservative think tanks (Mizruchi 2013). While a variety of issues were on the business agenda, the relaxation of antitrust enforcement in the face of global competition was clearly among them (Waterhouse 2013), and the impact of this new political cooperation would be felt in the antitrust field.

\section{The Triumph of Chicago in the Academic Field}

As the environment for antitrust policy was changing, the academic field was evolving rapidly as well. Chicago was rapidly replacing SCP as the dominant approach to industrial organization. By 1974, when Columbia Law faculty held a conference in northern Virginia at Airlie House that carefully pitted structuralists against Chicago types, the tide had turned: "[a]lthough a majority of antitrust economists and legal scholars prior to this debate almost certainly believed that competition was a major problem, that consensus collapsed" (Muris 1997:306; see also Leary 2001). The causes of this shift were complex.

On the one hand, some of it was driven by stakes internal to the academic field. During the 1960s, Chicago scholars continued to hammer away at the foundational assumptions of structuralism. They argued that predatory pricing did not exist; that restraints were created to 
advance efficiency, not to exercise market power; that barriers to entry were relatively insignificant, given access to capital markets; and that even very large firms would have trouble exercising market power, because doing so would attract new entrants. On the flip side, they showed there was no clear relationship between industry structure and firm conduct, as SCP claimed, and suggested that the observable relationship between concentration and profitability resulted from the fact that profitable firms tended to grow, not that firms in concentrated markets raised prices. ${ }^{24}$

These arguments were intellectually exciting, as reflected in the trajectories of a number of young scholars who switched sides during this period. As a young lawyer, Richard Posner had helped the government make its strong anti-merger case in Brown Shoe, but in the late 1960s he adopted the Chicago position, saying, "I think the most important [factor] was just that these people seemed very smart, analytically....They seemed smarter than lawyers...and in particular they were smarter in the sense that they had much better sharper analytical tools for dealing with the law" (Teles 2008:98). Similarly, William Baxter, Reagan's first antitrust chief and a strong Chicago advocate, signed on to the highly interventionist Neal Report in 1969 (Neal et al. 1969), but later recanted.

But Chicago's intellectual ascendance also aligned fortuitously with the interests of the increasingly organized business community. Henry Manne, an Antitrust Workshop alum who was a critical entrepreneur in the law and economics movement, found that between 1968 and 1971 it became much easier to raise industry money on its behalf: "At this point, the [corporate] world knew that Chicago economics was the only thing that could possibly save them from an antitrust debacle, and I related it strongly to that....Well, of the eleven [major corporations] I

\footnotetext{
${ }^{24}$ See McGee (1971), Goldschmidt et al. (1974) and Posner (1979) for summaries of some of these arguments.
} 
wrote to, within a few weeks I had $\$ 10,000$ from ten of them, and the last $\$ 10,000$ came in a few weeks later" (Teles 2008:107-108). Similarly, funders of the Airlie House conference, at which Chicago supporters saw themselves as having trounced SCP, read basically like a list of 1960s Antitrust Division targets: Alcoa, Amoco, Bethlehem Steel, Exxon, General Electric, General Motors, IBM, and so on. ${ }^{25}$

While it is impossible to fully untangle developments internal to the academic field from external resources as an explanation for the rise of Chicago ideas, the point is merely that both were favorable, and Harvard was clearly on the defensive. By 1975, when Don Turner and Philip Areeda published a landmark article on predatory pricing, they were forced to engage on Chicago's price-theoretic turf. They began by conceding to Chicago that "predatory pricing seems highly unlikely," then went on to argue that there were, in fact, occasional instances where price theory might expect it to exist (Areeda and Turner 1975:699). By 1979, Posner was, prematurely, declaring victory: "the diversity in fundamental premises among economists studying antitrust questions has substantially diminished....it is no longer worth talking about different schools of academic antitrust analysis" (Posner 1979:925).

\section{Linked Fields and the Chicago Move into Policy}

The strengthening links (Abbott 2005) that economists had worked to establish between the academic and policy fields meant that as academia changed, those changes would inevitably filter into the policy domain as well. The initial increase in the role played by economics at the $\mathrm{AD}$ and FTC may have been facilitated by the changing political environment, but was not driven primarily by organized business interests. Nor was it championed by strong Chicago

\footnotetext{
${ }^{25}$ See Goldschmid et al. (1974) for a list of eighteen sponsors, seventeen of which were large corporations.
} 
advocates.

But the EPO and the Bureau of Economics were steadily hiring new $\mathrm{PhDs}$, and increasingly, as the discipline shifted, those $\mathrm{PhDs}$ were oriented toward Chicago. By the late 1970s, "[m]ost of the staff [of the Bureau had] attended institutions that are generally described as satellites of the University of Chicago" and took a minimalist approach to antitrust enforcement (Katzmann 1980:38-39). This evolution sometimes led to conflict within the economics offices themselves. As Kauper recalled of Antitrust Division in the mid-1970s, "our own economists disagreed, both with each other and with many outside the Division. Where economic consensus was lacking, economic analysis was of far less utility, not only within the Division, but in attempting to influence formulation of doctrine by courts" (Kauper 1984:126127).

This double shift—-toward economics within the agencies, and toward Chicago within economics - meant that by the late 1970s, the economics offices sometimes acted as a brake on agency leadership. For example, Carter AAG John Shenefield supported strict size tests on mergers and "acknowledged he was going after bigness as such." Yet after promising to bring a "shared monopolies" case within six months, Shenefield was forced to recant " "because we didn't know and we do not know' the outcome of a lengthy staff investigation" (Cowan 1978; Cowan 1979). As economics became more important within the agencies, and as more attorneys were exposed to basic economic arguments - whether at law school or through in-agency training - the economic perspective increasingly shaped agency decisions.

The Supreme Court, too, increasingly subscribed to an economic conception of antitrust policy, rather than one attentive to small business or the political power of firms, and over the course of the decade moved to an explicitly Chicago-centered view. In the Sylvania case (1977), 
the Court rejected an earlier decision that had ruled nonprice vertical restraints as per se illegal, pointing out that "[e]conomists have identified a number of ways in which manufacturers can use such restrictions to compete more effectively against other manufacturers," and that they "also have argued that manufacturers have an economic interest in maintaining as much intrabrand competition as is consistent with the efficient distribution of their products."26

Similarly, Brunswick (1977) decided that private antitrust litigants could not simply rely on the size of the firm that would result from the merger, and the possibility that it might drive smaller competitors out of business, as the sole basis for a legal challenge. ${ }^{27}$ And in Sonotone (1979), the court stated, citing Robert Bork, that "Congress designed the Sherman Act as a 'consumer welfare prescription"”-which Bork (1978) had defined as meaning total (consumer plus producer) surplus. ${ }^{28}$ As one leading antitrust scholar has observed, "This singular normative vision proved foundational to the reorientation of antitrust law away from an interventionist, populist, Brandeisian, and vaguely Jeffersonian conception of antitrust law as a constraint on large-scale business power and toward a conception of antitrust law as a mild constraint on a relatively small set of practices that pose a threat to allocative efficiency" (Crane 2014:835). Economics had won over law, and Chicago had won over economics.

\section{Consolidating Chicago Economics in the 1980s Policy Field}

The Reagan era is often seen as a transformative one for antitrust policy. Reagan placed strong anti-enforcement figures, both of whom oversaw the decimation of their own agencies, at the head of both the Antitrust Division and the FTC. Yet much of the shift toward both economics

\footnotetext{
${ }^{26}$ Continental T.V., Inc., et al. v. GTE Sylvania Inc., 433 U.S. 36 (1977), at*54-*56.

${ }^{27}$ Brunswick Corp. v. Pueblo Bowl-O-Mat, Inc., et al., 429 U.S. 477 (1977).

${ }^{28}$ Reiter v. Sonotone Corp., 422 U.S. 330 (1979).
} 
and Chicago in the field of antitrust policy had already taken place by 1980 . The Reagan era was a period of consolidation of changes that were already taking place, rather than of fundamentally new developments.

At the Antitrust Division, Stanford Law professor William F. Baxter took the lead. Strongly committed to Chicago economics, Baxter agreed with the principal that there were only a small number of antitrust rules that were economically rational to enforce. Baxter requested a 14\% reduction in appropriations for the Division his first year in office (Kramer 1981:1298); that and subsequent rounds of budget-slashing meant that the number of professional staff decreased by almost half-from 352 in 1980 to 166 in 1986. These cuts fell disproportionately on attorneys, so the proportion of economists nearly doubled during the same period (Eisner 1991:190).

Baxter also oversaw two revisions of the Turner's 1968 merger guidelines. The main revision, published in 1982, created a new "safe harbor" for horizontal mergers in unconcentrated markets and gave the Division much more discretion about whether it would challenge such mergers in moderately concentrated markets. It also redefined "market" more broadly to include substitutes, which meant that fewer markets would appear concentrated in the first place (U.S. DOJ 1982; Werden 2002). The new guidelines generally followed the Chicago prescription of facilitating vertical and conglomerate mergers and only limiting horizontal mergers at very high levels of concentration.

By the end of the decade, even the more relaxed merger guidelines were infrequently enforced. A 1989 American Bar Association report found that "Division enforcement actions against conduct other than price-fixing and bid-rigging are extremely rare," with several types of enforcement abandoned entirely, and merger challenges having declined considerably. The 
Division had also taken to lobbying against antitrust rules, resulting in "a confusing message about whether the Division is dedicated to enforcing the antitrust laws as they have been interpreted in the courts" (Millstein et al. 1989:755, 756, 761).

At the same time Baxter was decimating the Antitrust Division, James C. Miller III, a Virginia-trained economist, was leading the FTC. After a rapid expansion of its authority during the 1970s (see, e.g., Pertschuk 1983), the agencies had targeted a number of industries (funeral homes, auto parts, the cereal industry) for antitrust action. But these industries turned to Congress to rein the agency in (Scherer 2009), and the FTC, now memorably named the "national nanny," nearly found itself abolished once again ("FTC" 1978).

While it was not abolished, under Miller it was severely chastened. Like Baxter, Miller "upgrade[d] and institutionalize[d] economic analysis at the commission," placing Chicago economists at the head of the Bureaus of Competition and Consumer Protection as well as the Bureau of Economics (Eisner 1991:50; Miller III 1989:213). And Miller, too, called for budget cuts, overseeing a budget reduction of roughly $50 \%$ in four years, with staff cuts to match (Eisner 1991:215). The FTC shifted away from merger challenges, approving "the nine largest mergers in the nation's history" between 1981 and 1984, and abandoned entirely the Robinson-Patman complaints that had been its bread and butter in the 1960s (Eisner 1991:221). While by the 1990s the antitrust pendulum would swing back in a slightly more interventionist direction, in the late 80s both economics and Chicago had, for the most part, come to thoroughly dominate antitrust policy.

\section{Post-Chicago: Game Theory Succeeds in the Academic Field but not in the Policy Field}

But even as the shift toward Chicago economics was consolidating in the field of antitrust policy 
in the 1980s, the academic field was already generating a response. In academia, the pendulum had swung decisively toward Chicago by the mid-1970s, as it had become increasingly clear that SCP, at least in its traditional form, was no longer a viable approach.

Yet just as Chicago appealed to those who believed that government rarely needed to intervene to maintain competitive markets, its implications were unappealing to those who found Chicago's assumptions unrealistic and thought much of the antitrust enterprise was necessary and important. Thus the decisive defeat of SCP by Chicago inevitably produced a fractal cycle in which "the concerns of the 'sterile' line [were] 'remapped' onto a version of the fertile one" (Abbott 2001:22). The main inheritor of the concerns of SCP was game theory.

Even before game theory became prominent within I/O, economists had pushed back on weak spots in the Chicago approach. Both Harvard and Chicago scholars had informally noted Chicago's neglect of the strategic and dynamic nature of firm decisions. A dominant firm might rationally execute a predatory strategy, for example, not to drive a competitor out of business (which Chicago suggested was pointless, as new competitors would enter as soon as the dominant firm tried to raise prices above the competitive level), but strategically, to lower its value in advance of a takeover (Giocoli 2014:22). But it took game theory, coming from a different part of the academic field and uniquely positioned to analyze strategic decisions, to formalize these critiques in ways that would once again transform I/O.

Game theorists had occasionally ventured into I/O prior to the late 1970s (e.g. Levitan and Shubik 1972; Shubik 1959); indeed, Stigler's classic (1964) paper on oligopoly treated it as a game. But the major advances took place after the development of Bayesian game theory (Harsanyi 1967-68), which allowed economists to model games in which the players had incomplete information (Giocoli 2009). 
Under conditions of perfect information, game theory seemed to support Chicago conclusions: for example, that no rational firm would ever participate in predatory pricing. But this result seemed counterintuitive in the face of the informal argument that firms would initially cut prices to teach potential competitors a lesson, but then shift to a less aggressive strategy. This "chain store paradox" (Selten 1978) led to the application of Bayesian techniques to I/O decisions, resulting in three landmark papers (Kreps and Wilson 1982a; Kreps and Wilson 1982b; Milgrom and Roberts 1982). These papers, and a flood of others that quickly followed, showed formally that under conditions of incomplete information, a host of practices that Chicago had said weren't rational for firms to pursue could, in fact, be rational under some conditions. This reopened the door to making the case for stronger antitrust policy on purely economic grounds (Giocoli 2014:25-46).

Bayesian game theory came from a very different location in the academic field from both Harvard SCP and Chicago price theory. Robert Wilson, David Kreps, Paul Milgrom and John Roberts were all associated with Stanford's Graduate School of Business; only Roberts' $\mathrm{PhD}$ was in economics. But in the 1980s the approach they pioneered rapidly swept I/O, replacing SCP and displacing, to a considerable extent, Chicago as well. Game theory lacked the external allies that had helped finance the dissemination of Chicago economics in the 1970s and beyond; the stakes of the academic field, not the policy field, appear to explain its spread in I/O. But it offered an exciting new way to formalize many of the stories structuralists had told informally, and to challenge the Chicago narrative, while providing an ever-greater level of rigor and mathematical sophistication. By the end of the decade, it had become the dominant approach (e.g. Kreps 1990; Schmalensee and Willig 1989; Tirole 1988; see also Giocoli 2014:28), known 
in antitrust as "post-Chicago". ${ }^{29}$

The new links between the academic field and the policy field provided a ready conduit for the transmission of game theory into the federal agencies. Just as in the 1970s new PhDs had increasingly being trained in the Chicago style, in the 1980s young economists were learning game theory. Accordingly, game-theoretic ideas were moving into the Antitrust Division and the FTC. David Scheffman, co-author of an important early article on strategic I/O (Salop and Scheffman 1983), led the FTC's Bureau of Economics in the late 1980s, and Robert Willig, who was quite friendly to game theory (see, e.g., Schmalensee and Willig 1989; Willig 1991), became deputy AAG for economics in 1989.

Initially, it appeared as if the new game-theoretic I/O might strongly affect antitrust policy, just as Chicago had a decade before. The post-Chicago impact could be seen, for example, in the 1992 revision of the Horizontal Merger Guidelines, which addressed the potential adverse effects of mergers in strategic terms: "Whether a merger is likely to diminish competition by enabling firms more likely, more successfully or more completely to engage in coordinated interaction depends on whether market conditions, on the whole, are conducive to reaching terms of coordination and detecting and punishing deviations from those terms" (Blumenthal 1993; U.S. DOJ and FTC 1992). Similarly, the Antitrust Division updated its Corporate Leniency Policy, meant to encourage cartel defectors, based on game-theoretic insights: it provided criminal immunity to the first member to report the cartel (Kovacic and Shapiro 2000:56; U.S. DOJ 1993).

There were even signs that the courts might recognize post-Chicago arguments in

\footnotetext{
${ }^{29}$ I am necessarily simplifying here. There are other economic approaches, like transaction cost economics and the theory of contestable markets, that have been significant in antitrust but fit neatly into neither SCP, Chicago, or postChicago boxes.
} 
antitrust cases, which would be critical to its long-term impact. While merger cases stopped reaching the Supreme Court after the 1970s, during the 1980s the Court had continued to apply Chicago principles to other potentially anticompetitive behaviors. ${ }^{30}$ In the landmark Matsushita case (1986), for example, the Court declared, citing several Chicago scholars, that "absent strong proof to the contrary," a defendant had no motive to engage in predatory pricing, because predatory pricing "simply makes no economic sense."31 This, reflected one economist, was "the sort of result that economists and economic theorists in particular fantasize about" (Salinger 2006:2).

But game theory challenged the presumption that predatory pricing was necessarily irrational, and in Kodak (1992), the Court acknowledged the change in the state of economic knowledge. ${ }^{32}$ The plaintiffs challenged Kodak's practice of selling replacement parts only to buyers who contracted with Kodak to service their machines, a form of "tying". Kodak, following Matsushita, argued that tying did not indicate the exercise of market power, because exercising such power "makes no economic sense": if the collective deal were worse, customers would simply switch to other suppliers. ${ }^{33}$ But, citing post-Chicago I/O, the Court pointed out the "the existence of significant information and switching costs" that meant, counter to Chicago, one could not simply assume no market power was being exercised and that a fuller evaluation was required (Tom 1997). ${ }^{34}$

Yet while these initial changes suggested post-Chicago might have significant effects on

\footnotetext{
${ }^{30}$ The Hart-Scott-Rodino Act of 1976 introduced pre-merger notification, which gave the Antitrust Division and FTC the authority to review mergers before they happened and request changes if they disapproved; between this and the general merger-friendly environment that prevailed from the late 1970s, the government largely stopped litigating mergers after the fact.

${ }^{31}$ Matsushita Elec. Indus. Co. v. Zenith Radio Corp., 475 U.S. 574 (1986) at 587.

${ }^{32}$ Eastman Kodak Co. v. Image Technical Services, 504 U.S. 451 (1992).

${ }^{33}$ Kodak at 466.

${ }^{34}$ Kodak at 473 .
} 
antitrust policy, after these tentative steps it hit a wall. In Brooke Group (1993), a predatory pricing case, the Supreme Court reinforced Matsushita and raised the bar even higher for the demonstration of predatory pricing, recommitting to a Chicago rather than post-Chicago interpretation (Giocoli 2014:255-256). ${ }^{35}$ The Kodak case, while initially hailed as a win for game theory, was found by lower courts to apply only subject "to a relatively demanding set of conditions" (Kovacic and Shapiro 2000:57). And even as I/O as a subfield of economics moved further and further past a straight Chicago interpretation of antitrust questions, the courts continued to apply Chicago economics - for example, in Leegin (2007), overturning a centuryold decision on the per se illegality of resale price maintenance on Chicago grounds. ${ }^{36}$

The difficulty, for the courts, was that game theory told too many stories. The policy implications of Chicago tended to be straightforward and easy for judges to apply. Practices like tying, resale price maintenance, nonprice vertical restraints, predatory pricing — all these had been seen as anticompetitive during the era of peak antitrust enforcement. Chicago simply said that they were not a problem, nor were mergers (in most cases), or high levels of industry concentration.

Post-Chicago, on the other hand, showed that under conditions of incomplete information, there were many circumstances under which such behaviors might exist, and might decrease market efficiency. But its answer to when they were a problem was, by and large, "it depends". While the new approach rigorously made the case that predatory pricing could be rational, or that restraints might lead to inefficient outcomes, it provided little guidance to whether such behaviors were anticompetitive in specific cases of the sort courts might encounter. Faced with such complexity, most judges decided to stick with certainty (Giocoli 2010). As one

\footnotetext{
35 Brooke Group Ltd. v. Brown \& Williamson Tobacco Corp., 509 U.S. 209 (1993).

${ }^{36}$ Leegin Creative Leather Products, Inc. v. PSKS, Inc., 551 U.S. 877 (2007).
} 
relatively neutral observer noted in 2001 ,

It now seems quite clear that Chicago School economic orthodoxy is no longer the best, or certainly not the only, analytic tool for evaluating markets. But the sad fact is that judges have not come close to developing antitrust rules that takes this messier, more complex economics into account. An even sadder fact is that in many instances judges may not be capable of doing so. As a result, the rather benign Chicago School rule may be the best one for policy purposes even though it does not do the best job of expressing what we know about economic theory (Hovenkamp 2001:271)

Thus a school of thought that was able to transform the academic field, even without a great deal of external resources to support it, lacked the affordances to be equally useful in the policy field, despite the fact that the academic and policy fields had become closely linked.

\section{Discussion}

Between about 1965 and 1980, economics became the dominant form of expertise in antitrust policy. The discipline gained this influence because of the entrepreneurial efforts of economists, favorable political circumstances, and support from allied interest groups. As the central role of economics was institutionalized, antitrust policy was narrowed from having several competing and sometimes conflicting goals, to having a single legitimate goal—maximizing efficiency in markets - and pursuing it through means consistent with the logic of economics.

But the capture of antitrust by experts did not remove politics from antitrust policy. Instead, politics was channeled through expertise. The relatively interventionist SCP framework that dominated when economists' star began to rise was replaced by the resolutely free-market Chicago School, which in turn was eclipsed by the game-theoretic Post-Chicago School, which was again friendlier to intervention. These schools of thought (particularly Chicago) were sometimes supported by ideological or economic interest groups from outside the academic field, but their success is not reducible to them; each school fractally generated its own opposition in 
academia, a la Abbott (2001), and while external resources were facilitating, they were not determinative.

Not all schools of thought, however, translated equally well from academic economics to antitrust policy: their political affordances differed. In particular, while both SCP and Chicago could be turned into rules that were relatively easy for courts to apply, game theory, while rigorous, offered no clear prescriptions about what judges should do to ensure consumer welfare (Giocoli 2014). Thus while game theory was ascendant in academic industrial organization by 1990, courts have continued to reiterate a Chicago approach to antitrust.

This gap between academic expertise and policy application suggests two lessons for those interested in the role of experts in the policy process. First, it is important to recognize the relative autonomy of the academic field from the policy field. While outside groups may support one school of thought or another, the development of academic disciplines is not determined solely by who has the most money, but also by stakes - including intellectual stakes - specific to the academic field. Similarly, while the academic and policy fields may be linked in ways that facilitate the transmission of people and ideas, the academic dominance of a particular approach (viz. game theory) does not necessarily translate to policy dominance, even given influential champions.

Second, while "capture" by economists did not end politics in antitrust policy—different groups of economists still advocated for more or less intervention in markets - it did constrain the terms of debate, so that nonmarket goals for antitrust policy were thoroughly delegitimated. While the effects of economics, or any form of expertise, on policy are likely to evolve over time, if the discipline in question has, like economics, a fairly durable "core" (Reay 2012), debate is likely to remain within parameters that are compatible with those core ideas, so long as 
the discipline that champions those ideas remains dominant.

These observations, however, are likely to apply only in policy domains in which economists have some kind of direct influence, along with links to a relatively autonomous academic field. For example, while economists are very visible in tax policy, they lack the same degree of control over policy decisions. While their ideas may be trotted out in support of one position or another, and their advice may even, on occasion, change someone's mind, academically illegitimate ideas (e.g. supply-side economics or the Laffer curve; see Berman and Milanes-Reyes 2013) appear to be just as politically useful as academically legitimate ones.

However, the degree of expert influence does not need to be as extensive as it is in antitrust for these dynamics to come into play. For example, while economists clearly do not control environmental policy, they do have meaningful footholds at the Environmental Protection Agency. In the modest areas they control, a focus on efficient solutions to environmental problems remains constant over time. Preferences for pollution taxes vs. emissions trading, which have different political implications, evolve, however, and understanding that evolution requires attention to the dynamics of the academic field.

Similarly, just because economists lack influence in a particular policy domain in the United States does not mean they lack it in all countries; Christensen (2017), for example, shows how economists had an institutionalized role in tax policy in New Zealand and Norway—but not Ireland and Denmark — and in those countries, the evolution of the academic field does seem relevant.

Finally, and more generally, this story has implications for the future of antitrust policy. The degree of government intervention in markets will continue to vary in conjunction with economists' ability to make new arguments about the effects of antitrust on consumer welfare, to 
the extent that policy decisions are made in administrative agencies by experts and evaluated by courts who defer to experts and require administrable rules. But the centrality of the consumer welfare conception of antitrust will continue to limit the scope of what antitrust options can legitimately be considered.

There are three possible ways such an equilibrium might be disrupted. One is that concerns about economic concentration that are not reducible to market power might be channeled into another, less technocratically restricted, policy domain, and implemented there. For example, the Consumer Financial Protection Bureau was created partly in response to concerns about the economic power of the financial sector that could, in theory if not in practice, have been addressed under the guise of antitrust law. Some antitrust economists (e.g. Wright 2012) have criticized the creation of the CFPB as "portend[ing] a deep rift in the intellectual infrastructure of consumer law that threatens the consumer-welfare oriented development of both [antitrust and consumer protection] bodies of law" (2216).

A second possibility is that political pressure might cause Congress to reintroduce other goals to antitrust policy through legislative means. This could similarly force agencies to pursue policies not linked to consumer welfare, narrowly defined, and would imply a relative loss of authority for economists in the antitrust domain.

Finally, a third option is that economics itself might evolve to change the status quo. If a new economic school of thought emerged that had different prescriptions for maximizing efficiency and also afforded more useful guidance to judges, it could potentially shift policy. ${ }^{37}$ Alternatively, while economists will almost certainly continue to focus on well-defined economic outcomes as opposed to, say, possible political effects of industrial concentration, over

\footnotetext{
${ }^{37}$ Behavioral economics is one obvious candidate, though it is not obvious that it offers much clearer administrative prescriptions than game theory.
} 
time the discipline might shift its focus to different economic measures-for example, by defining "consumer welfare" as consumer surplus rather than consumer plus producer surplus, or by making effects on innovation more central to evaluation of antitrust decisions. Either of these types of changes could have significant policy implications, but within the context of a policy domain still essentially defined by the discipline of economics. 


\section{Bibliography}

1978. "The FTC as National Nanny." in Washington Post. Washington.

Abbott, Andrew. 2001. Chaos of Disciplines. Chicago: University of Chicago Press.

—. 2005. "Linked Ecologies: States and Universities as Environments for Professions." Sociological Theory 23(3):245-74.

American Bar Association. 1969. Report of the ABA Commission to Study the Federal Trade Commission.

American Economic Review. 1983. "Joe S. Bain: Distinguished Fellow 1982." American Economic Review 73(3):n.p.

Areeda, Phillip E., and Donald F. Turner. 1975. "Predatory Pricing and Related Practices Under Section 2 of the Sherman Act." Harvard Law Review 88(4):697-733.

Barber, William J. 1996. Designs within Disorder: Franklin D. Roosevelt, the Economists, and the Shaping of American Economic Policy, 1933-1945. Cambridge: Cambridge University Press.

Berman, Elizabeth Popp. 2012. Creating the Market University: How Academic Science Became an Economic Engine. Princeton: Princeton University Press.

—. Forthcoming. "From Economic to Social Regulation: How the Deregulatory Moment Strengthened Economists' Policy Position." History of Political Economy.

Berman, Elizabeth Popp, and Laura M. Milanes-Reyes. 2013. "The Politicization of Knowledge Claims: The 'Laffer Curve' in the U.S. Congress." Qualitative Sociology 36:53-79.

Berman, Sheri. 1998. The Social Democratic Moment: Ideas and Politics in the Making of Interwar Europe. Cambridge: Harvard University Press.

Blumenthal, William. 1993. "Thirty-One Merger Policy Questions Still Lingering after the 1992 Guidelines." Antitrust Bulletin 38(3):593-641.

Blyth, Mark. 2002. Great Transformations: Economic Ideas and Institutional Change in the Twentieth Century. Cambridge: Cambridge University Press.

Bork, Robert. 1978. The Antitrust Paradox: A Policy at War with Itself. New York: Free Press.

Bourdieu, Pierre. 1993. "The Field of Cultural Production, or: The Economic World Reversed." Pp. 29-73 in The Field of Cultural Production, edited by Randal Johnson. New York: Columbia University Press.

Burgin, Angus. 2012. The Great Persuasion: Reinventing Free Markets since the Depression. Cambridge: Harvard University Press. 
Callon, Michel. 1986. "Some Elements of a Sociology of Translation: Domestication of the Scallops and the Fishermen of St. Brieuc Bay." Pp. 196-223 in Power, Action and Belief: A New Sociology of Knowledge?, edited by John Law. London: Routledge.

Campbell, John L. 1998. "Institutional Analysis and the Role of Ideas in Political Economy." Theory and Society 27:377-409.

—. 2002. "Ideas, Politics, and Public Policy." Annual Review of Sociology 28:21-38.

Campbell, John L., and Ove K. Pedersen. 2014. The National Origins of Policy Ideas: Knowledge Regimes in the United States, France, Germany and Denmark. Princeton: Princeton University Press.

Chamberlin, Edward. 1933. The Theory of Monopolistic Competition: A Re-Orientation of the Theory of Value. Cambridge: Harvard University Press.

Christensen, Johan. 2017. The Power of Economists within the State. Stanford: Stanford University Press.

Cowan, Edward. 1978. "Law for Size Limits on Mergers Sought." Pp. 25-26 in New York Times.

—. 1979. "Popularity for 'Big Is Bad' Idea Fades in Key Places." Pp. E3 in New York Times.

Cox, Edward Finch, Robert C. Fellmeth, and John E. Schulz. 1969. The Nader Report on the Federal Trade Commission. New York: Richard W. Baron Publishing Company.

Crane, Daniel A. 2014. "The Tempting of Antitrust: Robert Bork and the Goals of Antitrust Policy." Antitrust Law Journal 79(3):835-53.

Dameron, Charles S. 2016. "Present at Antitrust's Creation: Consumer Welfare in the Sherman Act's State Statutory Forerunners." Yale Law Journal 125(4):796-1149.

Davies, William. 2010. "Economics and the 'Nonsense' of Law: The Case of the Chicago Antitrust Revolution." Economy and Society 39:64-83.

-. 2014. The Limits of Neoliberalism: Authority, Sovereignty, and the Logic of Competition. Thousand Oaks, CA: SAGE Publications Ltd.

Derthick, Martha, and Paul J. Quirk. 1985. The Politics of Regulation. Washington, DC: Brookings Institution Press.

Director, Aaron, and Edward H. Levi. 1956. "Law and the Future: Trade Regulation." Northwestern University Law Review 51:281-96.

Dobbin, Frank. 1994. Forging Industrial Policy: The United States, Britain, and France in the Railway Age. Cambridge: Cambridge University Press.

Dobbin, Frank, and Timothy J. Dowd. 2000. "The Market that Antitrust Laws Built." American Sociological Review:631-57. 
Eisner, Marc Allen. 1991. Antitrust and the Triumph of Economics: Institutions, Expertise, and Policy Change. Chapel Hill: The University of North Carolina Press.

Eyal, Gil. 2013. "For a Sociology of Expertise: The Social Origins of the Autism Epidemic." American Journal of Sociology 118:863-907.

Eyal, Gil, and Larissa Buchholz. 2010. "From the Sociology of Intellectuals to the Sociology of Interventions." Annual Review of Sociology 36:117-37.

Fairbrother, Malcolm. 2014. "Economists, Capitalists, and the Making of Globalization: North American Free Trade in Comparative-Historical Perspective." American Journal of Sociology 119(5):1324-79.

Feldstein, Mark. 2010. Poisoning the Press: Richard Nixon, Jack Anderson, and the Rise of Washington's Scandal Culture. New York: MacMillan.

Fisher, Franklin M. 2012. "Carl Kaysen: 5 March 1920 - 8 February 2010." Proceedings of the American Philosophical Society 156:340-46.

Fligstein, Neil. 1990. The Transformation of Corporate Control. Cambridge: Harvard University Press.

Fligstein, Neil, and Doug McAdam. 2012. A Theory of Fields. Oxford: Oxford University Press.

Gaver, William W. 1991. "Technology Affordances." Proceedings of the SIGCHI Conference on Human Factors in Computing Systems:79-84.

Gibson, James J. 1977. "The Theory of Affordances." in Perceiving, Acting, and Knowing, edited by Robert Shaw and John Bransford.

Giocoli, Nicola. 2009. "Three Alternative (?) Stories on the Late 20th-Century Rise of Game Theory."24.

—. 2010. "Games Judges Don't Play: Predatory Pricing and Strategic Reasoning in U.S. Antitrust."61.

- 2014. Predatory Pricing in Antitrust Law and Economics: A Historical Perspective. New York: Routledge.

Goldschmid, Harvey J., H. Michael Mann, and J. Fred Weston (Eds.). 1974. Industrial Concentration: The New Learning. New York: Little, Brown \& Company.

Green, Mark J. 1972. The Closed Enterprise System: Ralph Nader's Study Group Report on Antitrust Enforcement: Bantam Books.

Greene, Hillary. 2006. "Guideline Institutionalization: The Role of Merger Guidelines in Antitrust Discourse." William and Mary Law Review 48:771-857. 
Hall, Peter A. (Ed.). 1989. The Political Power of Economic Ideas: Keynesianism across Nations. Princeton, NJ: Princeton University Press.

—. 1993. "Policy Paradigms, Social Learning and the State: The Case of Economic Policymaking in Britain." Comparative Politics 25:275-96.

Harris, Richard A., and Sidney M. Milkis. 1996. The Politics of Regulatory Change: A Tale of Two Agencies. Oxford: Oxford University Press.

Harsanyi, John C. 1967-68. "Games with Incomplete Information Played by Bayesian Players, IIII." Management Science 14(3):159-83, 320-34, 486-502.

Hay, George H. 2008. "Oral History." edited by Ky P. Ewing: American Bar Association, Section of Antitrust Law, Public Education and Oral History Committee.

Hovenkamp, Herbert. 1985. "Antitrust Policy after Chicago." Michigan Law Review 84(2):21384.

—. 2001. "Post-Chicago Antitrust: A Review and Critique." Columbia Business Law Review 2001:257-337.

—. 2009. "United States Competition Policy in Crisis: 1890-1955." Minnesota Law Review 94:311-67.

-. 2015. The Opening of American Law: Neoclassical Legal Thought, 1870-1970. Oxford: Oxford University Press.

Katzmann, Robert A. 1980. Regulatory Bureaucracy: The Federal Trade Commission and Antitrust Policy. Cambridge, MA: MIT Press.

Kauper, Thomas E. 1969. "The 'Warren Court' and the Antitrust Laws: Of Economics, Populism, and Cynicism." Michigan Law Review 67(325-342).

—. 1984. "The Role of Economic Analysis in the Antitrust Division Before and After the Establishment of the Economic Policy Office: A Lawyer's View." Antitrust Bulletin 29:111-32.

—. 2007. "Oral History." edited by Donald C. Klawiter: American Bar Association, Section of Antitrust Law, Public Education and Oral History Committee.

Kovacic, William E., and Carl Shapiro. 2000. "Antitrust Policy: A Century of Legal and Economic Thinking." Journal of Economic Perspectives 14:43-60.

Kramer, Victor H. 1981. "Antitrust Today: The Baxterization of the Sherman and Clayton Acts." Wisconsin Law Review 1981:1287-302.

Kreps, David M. 1990. A Course in Microeconomic Theory. Princeton: Princeton University Press. 
Kreps, David M., and Robert Wilson. 1982a. "Reputation and Imperfect Information." Journal of Economic Theory 27:253-78.

—. 1982b. "Sequential Equilibria." Econometrica 50(4):863-94.

Lande, Robert H. 1982. "Wealth Transfers as the Original and Primary Concern of Antitrust: The Efficiency Interpretation Challenged." Hastings Law Journal 34:65-151.

Leary, Thomas B. 2001. "Antitrust Economics: Three Cheers and Two Challenges." Federal Trade Commission.

Levinson, Marc. 2011. The Great A\&P and the Struggle for Small Business in America.

Levitan, Richard, and Martin Shubik. 1972. "Price Duopoly and Capacity Constraints." International Economic Review 13(1):111-22.

Liu, Sida, and Mustafa Emirbayer. 2016. "Field and Ecology." Sociological Theory 34(1):62-79.

Markus, Lewis. 1962. "The Role of Economics in Department of Justice Enforcement of the Antitrust Laws." ABA Antitrust Section 20:13-19.

Mayhew, Anne. 1998. "How American Economists Came to Love the Sherman Antitrust Act." History of Political Economy 30(4):179-201.

McGee, John S. 1958. "Predatory Price Cutting: The Standard Oil (N.J.) Case." Journal of Law and Economics 1:137-69.

—. 1971. In Defense of Industrial Concentration. New York: Praeger Publishers.

McNamara, Kathleen. 1998. The Currency of Ideas: Monetary Politics in the European Union. Ithaca, NY: Cornell University Press.

Medema, Steven G. 1998. "Wandering the Road from Pluralism to Posner: The Transformation of Law and Economics in the Twentieth Century." History of Political Economy 30:20224.

Medvetz, Thomas. 2012. Think Tanks in America. Chicago: University of Chicago Press.

Milgrom, Paul, and John Roberts. 1982. "Predation, Reputation and Entry Deterrence." Journal of Economic Theory 27:280-312.

Miller III, James C. 1989. The Economist as Reformer: Revamping the FTC, 1981-1985. Washington, DC: American Enterprise Institute.

Miller, John J. 2006. A Gift of Freedom: How the John M. Olin Foundation Changed America: Encounter Books.

Millon, David K. 1988. "The Sherman Act and the Balance of Power." Southern California Law Review 61:1219-92. 
Millstein, Ira M., and et al. 1989. "Report of the ABA Antitrust Section Task Force on the Antitrust Division of the U.S. Department of Justice." Antitrust Law Journal 58:737-93.

Mizruchi, Mark. 2013. The Fracturing of the American Corporate Elite. Cambridge: Harvard University Press.

Mudge, Stephanie Lee, and Antoine Vauchez. 2012. "Building Europe on a Weak Field: Law, Economics, and Scholarly Avatars in Transnational Politics." American Journal of Sociology 118:449-92.

Mueller, Willard F. 1962. "The Role of Economics in Antitrust Enforcement at the Federal Trade Commission." ABA Antitrust Section 20:20-28.

—. 2009. Fighting for Antitrust Policy: Xlibris.

Muris, Timothy J. 1997. "Economics and Antitrust." George Mason Law Review 5:303-12.

Neal, Phil C., and et al. 1969. "Report of the White House Task Force on Antitrust Policy." Antitrust Law and Economics Review 2:11-52.

Newborn, Steven A., and Virginia L. Snider. 1992. "The Growing Judicial Acceptance of the Merger Guidelines." Antitrust Law Journal 60:849-56.

Norman, Donald A. 1990. "Cognitive Artifacts." in Designing Interaction, edited by John M. Carroll. Cambridge: Cambridge University Press.

Orbach, Barak. 2013. "How Antitrust Lost Its Goal." Fordham Law Review 81:2253-.

Patman, Wright, and Joseph Robinson. 1938. The Robinson-Patman Act: What You Can and Cannot Do Under This Law. New York: Ronald Press Company.

Pautler, Paul A. 2015. "A History of the FTC's Bureau of Economics." American Antitrust Institute.

Peritz, Rudolph J. R. 1996. Competition Policy in America: History, Rhetoric, Law. New York: Oxford University Press.

Pertschuk, Michael. 1983. Revolt Against Regulation: The Rise and Pause of the Consumer Movement. Berkeley: University of California Press.

Posner, Richard A. 1979. "The Chicago School of Antitrust Analysis." University of Pennsylvania Law Review 127:925-48.

Prasad, Monica. 2006. The Politics of Free Markets: The Rise of Neoliberal Economic Policies in Britain, France, Germany, and the United States. Chicago: University of Chicago Press.

- 2012. The Land of Too Much: American Abundance and the Paradox of Poverty. Cambridge: Harvard University Press. 
Reay, Michael J. 2012. "The Flexible Unity of Economics." American Journal of Sociology 118:45-87.

Robinson, Joan. 1933. The Economics of Imperfect Competition. London: Macmillan and Co., Ltd.

Salinger, Michael A. 2006. "The Legacy of Matsushita: Has This Thing Called Economics Gotten Way Out of Hand?".

Salop, Steven C., and David T. Scheffman. 1983. "Raising Rivals' Costs." American Economic Review 73(2):267-71.

Scherer, Frederic M. 2009. "Oral History." edited by Philip J. Weiser: American Bar Association, Section of Antitrust Law, Public Education and Oral History Committee.

Schmalensee, Richard, and Robert D. Willig (Eds.). 1989. The Handbook of Industrial Economics. Amsterdam: North-Holland.

Selten, Reinhard. 1978. "The Chain-Store Paradox." Theory and Decision 9:127-59.

Shanahan, Eileen. 1966. "Antitrust Chief With a Sophisticated View." Pp. 61, 65 in New York Times.

Shepherd, William G. 2007. "Edward S. Mason." Pp. 209-10 in Pioneers of Industrial Organization: How the Economics of Competition and Monopoly Took Shape, edited by Henry W. de Jong and William G. Shepherd. Northampton, MA: Edward Elgar.

Shubik, Martin. 1959. Strategy and Market Structure: Competition, Oligopoly, and the Theory of Games. New York: John Wiley \& Sons.

Simons, Henry C. 1948. Economic Policy for a Free Society. Chicago: University of Chicago Press.

Sims, Joe, and Deborah P. Herman. 1997. "The Effect of Twenty Years of Hart-Scott-Rodino on Merger Practice: A Case Study in the Law of Unintended Consequences Applied to Antitrust Legislation." Antitrust Law Journal 65:865-904.

Somers, Margaret R., and Fred Block. 2005. "From Poverty to Perversity: Ideas, Markets, and Institutions over 200 Years of Welfare Debate." American Sociological Review 70:26087.

Stigler, George J. 1961. "The Economics of Information." Journal of Political Economy 69:21325.

—. 1964. "A Theory of Oligopoly." Journal of Political Economy 44:44-61.

Stigler, George J., and Claire Friedland. 1962. "What Can Regulators Regulate? The Case of Electricity." Journal of Law and Economics 5:1-16. 
Tavory, Iddo, and Stefan Timmermans. 2014. Abductive Analysis: Theorizing Qualitative Research. Chicago: University of Chicago Press.

Teles, Steven M. 2008. The Rise of the Conservative Legal Movement: The Battle for Control of the Law. Princeton: Princeton University Press.

Thornton, Patricia H., William Ocasio, and Michael Lounsbury. 2012. The Institutional Logics Perspective: A New Approach to Culture, Structure, and Process. Oxford, UK: Oxford University Press.

Tirole, Jean. 1988. The Theory of Industrial Organization. Cambridge: MIT Press.

Turner, Donald F. 1964. "Conglomerate Mergers and Section 7 of the Clayton Act." Harvard Law Review 78:1313-95.

U.S. Department of Justice, and Federal Trade Commission. 1992. Horizontal Merger Guidelines. Washington, DC: U.S. Government Printing Office.

U.S. Department of Justice, Antitrust Division. 1968. 1968 Merger Guidelines. Washington, DC: U.S. Government Printing Office.

—. 1982. 1982 Merger Guidelines. Washington, DC: U.S. Government Printing Office.

—. 1993. Corporate Leniency Policy. Washington, DC: U.S. Government Printing Office.

Van Horn, Robert. 2009. "Reinventing Monopoly and the Role of Corporations." Pp. 204-37 in The Road from Mont Pelerin: The Making of the Neoliberal Thought Collective, edited by Philip Mirowski and Dieter Plehwe. Cambridge: Harvard University Press.

Van Horn, Robert, and Philip Mirowski. 2009. "The Rise of the Chicago School of Economics and the Birth of Neoliberalism." Pp. 139-78 in The Road from Mont Pelerin: The Making of the Neoliberal Thought Collective, edited by Philip Mirowski and Dieter Plehwe. Cambridge: Harvard University Press.

Wagner, Susan. 1971. The Federal Trade Commission. New York: Praeger Publishers.

Waterhouse, Benjamin C. 2013. Lobbying America: The Politics of Business from Nixon to NAFTA. Princeton: Princeton University Press.

Weaver, Suzanne. 1977. Decision to Prosecute: Organization and Public Policy in the Antitrust Division. Cambridge, MA: MIT Press.

Weir, Margaret. 1993. Politics and Jobs: The Boundaries of Employment Policy in the United States. Princeton: Princeton University Press.

Weir, Margaret, and Theda Skocpol. 1983. "State Structures and Social Keynesianism: Responses to the Great Depression in Sweden and the United States." International Journal of Comparative Sociology 24:4-29. 
Werden, Gregory J. 2002. "The 1982 Merger Guidelines and the Ascent of the Hypothetical Monopolist Paradigm." in 20th Anniversary of the 1982 Merger Guidelines: The Contribution of the Merger Guidelines to the Evolution of Antitrust Doctrine. Washington, DC.

Williamson, James R. 1995. Federal Antitrust Policy during the Kennedy-Johnson Years: Greenwood Publishing Group.

Williamson, Oliver E. 2002. "The Merger Guidelines of the U.S. Department of Justice -- In Perspective." in 20th Anniversary of the 1982 Merger Guidelines: The Contribution of the Merger Guidelines to the Evolution of Antitrust Doctrine. Washington, DC.

Willig, Robert D. 1991. "Merger Analysis, Industrial Organization Theory, and Merger Guidelines." Brookings Papers: Microeconomics:281-332.

Wright, Joshua D. 2012. "The Antitrust/Consumer Protection Paradox: Two Policies at War with Each Other." Yale Law Journal 121:2216-68.

Zimmerman, Edwin M. 1990. "Section 7 and the Evolving Role of Economics." Antitrust Bulletin 35:447-65. 